\title{
Molecular implications of prolonged aggression experience: Th, Dat1, Snca and Bdnf gene expression in the ventral tegmental area of the victorious male mice
}

\author{
N.P.Bondar ${ }^{1,3}$, U.A. Boyarskikh ${ }^{2,3}$, I.L. Kovalenko ${ }^{1}$, M.L. Filipenko ${ }^{2,4}$, N.N. Kudryavtseva ${ }^{1,5}$ \\ ${ }^{1}$ Institute of Cytology and Genetics SD RAS, Novosibirsk, Russia; ${ }^{2}$ Institute of Chemical Biology and Basic \\ Medicine SD RAS, Novosibirsk, Russia
}

\begin{abstract}
Th, Dat1, Snca and Bdnf were the genes whose mRNA levels in the ventral tegmental area of the midbrain were measured in male mice that were victorious in 20 daily agonistic interactions and in a group of such victorious mice that had later not been allowed to fight for 14 days. This experiment demonstrated increased Th, Dat1 and Snca but not Bdnf mRNA levels in the former group as compared to the controls. In the latter group, the expression of the Th and Dat1 genes was still enhanced, while the level of Snca mRNA did not differ from that in the controls. These findings suggest that positive fighting experience enhances the expression of the genes concerned with dopaminergic systems and this enhanced expression is preserved for a long time afterwards. Significant positive correlations were found between the level of aggression and Th and Snca mRNA levels in the winners.
\end{abstract}

Keywords: repeated aggression, Th, Dat1, Snca, Bdnf, mRNA, aggression deprivation, sensory contact model, mice.

\section{Introduction}

It is well known that recurrent aggression may be consequences of many psychiatric disorders such as manic-depressive disorder, compulsive-obsessive disorder, epilepsy, posttraumatic stress, autism, Alzheimer's disease, attention deficit/hyperactivity disorder, mental retardation, schizophrenia, drug abuse etc ${ }^{1}$. According to many authors ${ }^{2-6}$, aggression is rewarding in laboratory rodents and humans and any positive reinforcement increases the propensity to behave aggressively. It was shown experimentally that male mice who were consistently gaining positive fighting experience in daily agonistic interactions (winners) developed behavioral psychopathology, which included the demonstration of pathological aggression, malignancy and strong hostility ${ }^{6,7}$. Total activation of the brain dopaminergic systems is due to increased dopamine (DA) turnover, which leads to DOPAC formation in various brain areas (olfactory bulbs, amygdala, hippocampus, nucleus accumbens, striatum and midbrain), was shown in winners ${ }^{8,9}$. A number of papers confirms the involvement of brain dopaminergic systems in the control of aggressive behavior ${ }^{10,11}$.

We have recently found ${ }^{12}$ that the chronic manifestation of aggression by male mice who had won 10 daily fights enhanced the expression of the tyrosine hydroxylase (Th) gene and the dopamine transporter (Dat1) gene in their ventral tegmental area (VTA), the key brain area underlying reward ${ }^{13}$. The aim of our paper was to study the mRNA levels of the genes that may possibly be involved in repeated aggression - Th, Dat1, the alpha-synuclein (Snca) gene and the brain-derived neurotrophic factor (Bdnf) gene in the VTA of the winners with 20-day positive fighting experience, which, as was demonstrated earlier, leads to the development of pathological aggression ${ }^{6}$. The expression of these genes was also studied in a group of 20-day winners who had not been allowed to fight for 14 days; these animals were special in that they were more aggressive after than before this 14-day period ${ }^{6}$, which we call "aggression deprivation" or "deprivation" throughout. The comparison of the levels of

Correspondence: Dr Kudryavtseva N.N. Institute of Cytology and Genetics SD RAS, pr. Ak. Lavrentjeva 10, Novosibirsk, 630090, Russia, natnik@bionet.nsc.ru

${ }^{3}$ These authors made an equal contribution to this paper. ${ }^{4}$ Dr. Filipenko M.L. was responsible for the molecular aspect of this work. ${ }^{5}$ Dr. Kudryavtseva N.N. was responsible for the behavioral aspect of this work. 
expression of these genes in no-deprivation and post-deprivation settings helps answer the question as to whether or not the levels of gene expression in the VTA of the post-deprivation winners recovers to that in the controls or no-deprivation winners.

\section{Materials and Methods}

\section{Animals}

Adult male mice of the C57BL/6J strain stock were maintained in Institute of Cytology and Genetics SD RAS, Novosibirsk, Russia. The animals were kept under standard housing conditions with a light:dark cycle of 12:12h, with the light switched on at 8.00 a.m. Food (pellets) and water were available ad libitum. One-month-old males were weaned and housed in groups of 8-10 in plastic $36 \times 23 \times 12-\mathrm{cm}$ cages. Experimental mice were 10-12 weeks of age. All procedures were in compliance with European Communities Council Directive of 24 November 1986 (86/609/EEC).

\section{Winners}

To induce aggressive behavior in male mice, the sensory contact model was used as previously described in detail ${ }^{14}$. Animals of the same weight were placed by pairs in steel cages $(28 \times 14 \times 10 \mathrm{~cm})$ divided into equal compartments by a perforated transparent partition permitting the mice to see, hear and sense the smell of the neighbor, whilst preventing physical contact. After two days of adaptation to the housing conditions and sensory contact, testing commenced. Daily, in the second half of the 12-h light phase, the steel cover of the cage was replaced by a transparent one and 5 min later the partition was removed for 10 min to allow agonistic interaction. Superiority of one of the partners was evident within 2 or 3 tests in daily social encounter with the same opponent. One member of each pair attacked, bit, and chased the other who displayed only defensive behavior (sideways, upright postures, and also 'on the back' or 'freezing') during the test. Aggressive confrontations between males were discontinued by lowering the partition if the aggression had lasted more than $3 \mathrm{~min}$. Every day after the test, each defeated male (a loser) of a pair was paired with a winning member of another pair behind the partition in an unfamiliar cage. The aggressive males (winners) remained in their own compartments. This procedure resulted in equal numbers of animals with opposite social status. The experimental design is presented in Fig. 1. Three animal groups were studied in this experiment: 1) No-deprivation winners: aggressive males that were victorious in 20 daily agonistic confrontations; 2) Post-deprivation winners: a group of 20-day winners who had not been allowed to fight for 14 days. During deprivation, each winner was sharing the experimental cage with a loser in the neighboring compartment, and the partition was never removed; 3) Control males were housed

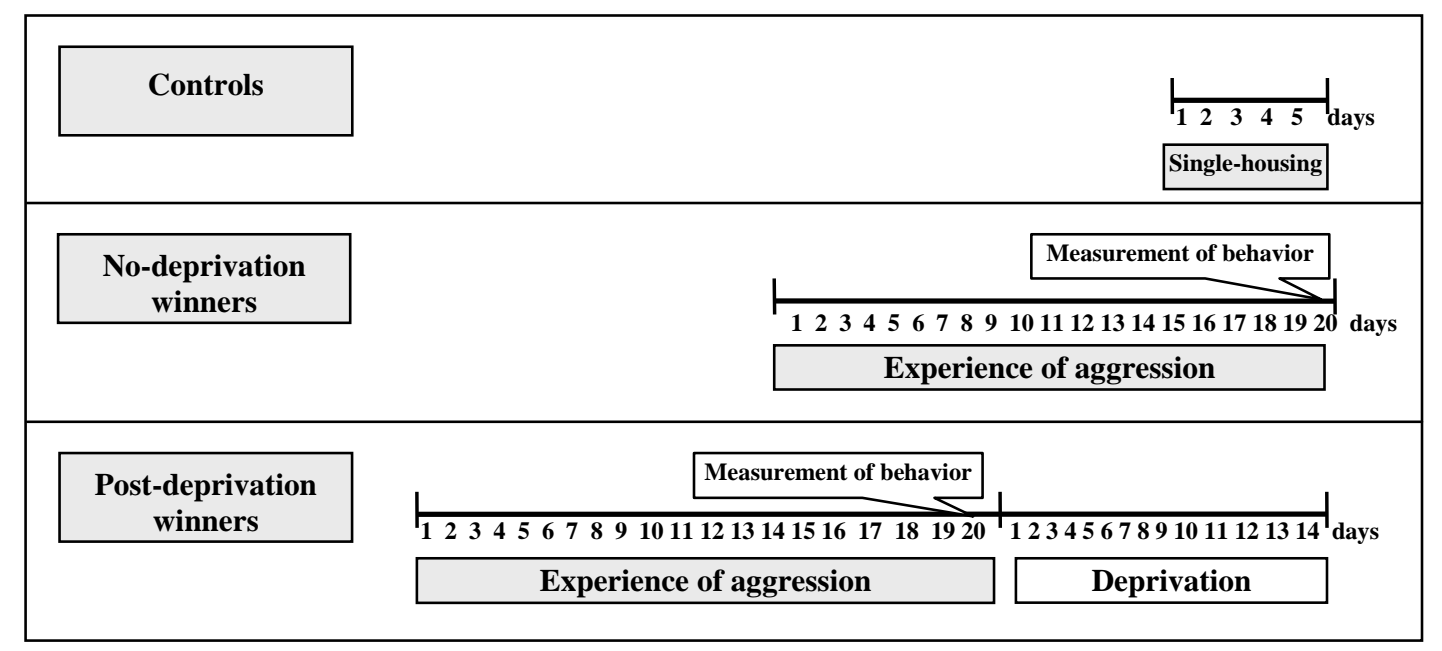

Figure 1. Protocol of experiment. Behavior in no-deprivation and post-deprivation winners was recorded on day 20 of agonistic interactions 
individually for 5 days. They were regarded as the most appropriate controls for the sensory contact model, because the submissiveness of grouped males was removed, and the effects of social isolation were not yet acquired (for details see ${ }^{14}$ ).

\section{Behavioral study}

The behavior of victorious mice in both groups was video recorded for 10 minutes during the last $\left(20^{\text {th }}\right)$ agonistic confrontation (Fig. 1). After documenting the behavioral data recorded, we compared the behavioral parameters in the mice of both groups. This comparison was made in order to find out whether both groups could be considered identical in terms of aggressive and individual behavior. If the groups were found identical indeed, then all the differences in gene expression (or the lack of such differences) between post-deprivation and no-deprivation winners would solely be due to deprivation.

The following behavioral domains were analyzed: 1. Attacking: Attacking, biting and chasing; 2. Aggressive grooming: The winner mounts onto the loser's back, holds it down and intensively nibbles and licks it for a long time, mainly at the scruff area. The loser is wholly immobilized, often stretches out the neck and freezes under the winners; 3. Digging: herein: Digging up and scattering the sawdust on the loser's territory: kick digs or push digs the sawdust forward or backward with the forepaws or hind paws; 4. Self-grooming: Body care activities (licking of the fur on the flanks or abdomen, washing over the head from ear to snout). The parameters of the behavioral domains were as follows: a. Latency to the first event (for 1-2), seconds; b. Total time so doing (for 1-4), seconds; c. Number of events (for 1-4). If an animal did not display attacks or aggressive grooming, the latency to these events was recorded as $600 \mathrm{~s}$ (i.e. how long the test lasted) and all the other counts were recorded as zero. The total time spent attacking, aggressively grooming and digging was used as an index of hostile behavior.

\section{Genes and the brain area}

The Th, Dat1, Snca and Bdnf genes were chosen on the basis of a possible role of their products (proteins) in the dopaminergic regulation of aggressive behavior: $\mathrm{TH}$, the rate-limiting enzyme of DA synthesis; DAT, terminates the DA action on the postsynaptic membrane by rapidly removing it from the synaptic cleft via reuptake ${ }^{15-17} ; \alpha$-Syn plays a role in dopamine compartmentalization in the presynaptic terminals and this is the mechanism by which transient dopamine is released ${ }^{18,}, 19$. Observations suggest that the possible primary function of $\alpha$-Syn in dopaminergic neurons is the regulation of dopamine synthesis, storage in vesicles, release in the synapse, and re-uptake into the dopaminergic neurons ${ }^{20}$; BDNF, which is involved in the development of many diseases ${ }^{21,22}$ by participating in the differentiation, growth and maintenance of selected peripheral and central populations of neuronal cells.

The present study is focused on the VTA of the midbrain, containing the cell bodies of mesolimbic dopaminergic neurons. It is well known that mesolimbic dopaminergic projections from the VTA play an important role in the mediation of the rewarding processes and are involved in many kinds of social behavior ${ }^{13,23}$.

To measure mRNA levels in VTA, all the mice were decapitated simultaneously: nodeprivation winners, 24 hours after the last agonistic interaction; post-deprivation winners, immediately after 14-day deprivation; and the controls, on day 6 of individual housing (Fig. 1). The mouse brains were removed and chilled rapidly on ice. The VTA was dissected according to the Mouse Brain Atlas ${ }^{24}$ and was obtained from sections cut at levels located between $1.68 \mathrm{~mm}$ before to $-2.12 \mathrm{~mm}$ after Bregma. Obtained tissue was rapidly frozen in liquid nitrogen and stored at $-70^{\circ} \mathrm{C}$ until used.

\section{Total RNA extraction and reverse transcription}

Total RNA was extracted from each individual brain tissue sample using the method of Chomczynski and $\mathrm{Sacchi}^{25}$ with modifications. The quantity of total RNA was measured by absorbance at $260 \mathrm{~nm}$. 
The integrity of total RNA was verified by agarose gel electrophoresis. $1 \mu \mathrm{g}$ of total RNA was used for cDNA synthesis by MoMLV reverse transcriptase (Biosan, Novosibirsk, Russia).

\section{Real-time quantitative PCR}

Amplification, data acquisition and analysis were performed using an iQ5 Cycler (Bio-Rad, Hercules, CA, USA). Th, Dat1, Bdnf, $\beta$-actin (Actb), and cyclophilin (Cphn) mRNA levels were quantified by TaqMan real-time PCR analysis. PCR was performed in a total volume of $25 \mu \mathrm{l}$ of solution containing an aliquot of RT mixture, dNTPs, sense and anti-sense primers, TaqMan probe, PCR buffer, and hotstart Taq DNA polymerase (Biosan, Novosibirsk, Russia). Amplification conditions were as follows: $2 \mathrm{~min}$ at $96^{\circ} \mathrm{C}$, followed by 37 cycles of $15 \mathrm{~s}$ at $96^{\circ} \mathrm{C}, 45 \mathrm{~s}$ at $61^{\circ} \mathrm{C}$ and a fluorescence detection step.

Snca mRNA levels were quantified by SybrGreenI real-time PCR analysis. PCR was performed in a total volume of $25 \mu \mathrm{l}$ of solution containing an aliquot of RT mixture, dNTP, sense and anti-sense primers, Sybr Green I (Invitrogen), PCR buffer, and hot-start Taq DNA polymerase. Amplification conditions were as follows: $3 \mathrm{~min}$ at $95^{\circ} \mathrm{C}$, followed by 40 cycles of $10 \mathrm{~s}$ at $92^{\circ} \mathrm{C}, 6 \mathrm{~s}$ at $60^{\circ} \mathrm{C}$, and $6 \mathrm{~s}$ at $72^{\circ} \mathrm{C}$. Fluorescence was detected at $85^{\circ} \mathrm{C}$ for $10 \mathrm{~s}$. A melting curve analysis was added after the final PCR cycle to check for the presence of non-specific PCR products and primer dimmers. The amplification efficiency and cDNA concentration range with a constant PCR efficiency were defined by constructing a calibration curve from fourfold serial dilutions of pooled cDNA. In all cases, the amplification efficiency was more than $85 \%$. All samples were analyzed twice.

Table 1. Primers and probes sequences

\begin{tabular}{|c|c|c|}
\hline Genes & & Primers and probes sequences \\
\hline \multirow[t]{3}{*}{ Bdnf } & sense & 5'-ACTATGGTTATTTCATACTTCGGTT-3' \\
\hline & anti-sense & 5'-CCATTCACGCTCTCCAGA-3' \\
\hline & probe & 5'-FAM-CGTCCACGGACAAGGCAACTT-BHQ1-3' \\
\hline \multirow[t]{3}{*}{ Dat1 } & sense & 5'- GTGTCCAGCAATTCAGTGAT-3' \\
\hline & anti-sense & 5'-TGACCACGACCACATACAGA-3' \\
\hline & probe & 5'- FAM-CCAGCATAGCCGCCAGTACAGG-BHQ1-3' \\
\hline \multirow[t]{3}{*}{ Th } & sense & 5'-TTGGATAAGTGTCACCACCTG-3' \\
\hline & anti-sense & 5'-TGGCTCACCCTGCTTGTA-3' \\
\hline & probe & 5'-R6G-TGACCCTGACCTGGACCTGGAC-BHQ1-3' \\
\hline \multirow[t]{2}{*}{ Snca } & sense & 5'-TGACAGCAGTCGCTCAGA-3' \\
\hline & anti-sense & 5'-CATGTCTTCCAGGATTCCTTC-3' \\
\hline \multirow[t]{3}{*}{ Cphn } & sense & 5'-GAGAACTTCATCCTAAAGCATACAG-3' \\
\hline & anti-sense & 5'-TCACCTTCCCAAAGACCA-3' \\
\hline & probe & 5'- TAMRA -CGTTGCCATCCAGCCATTCAG-BHQ2-3' \\
\hline \multirow[t]{3}{*}{ Actb } & sense & 5'- TCTTTGCAGCTCCTTCGTT -3’ \\
\hline & anti-sense & 5'-CGATGGAGGGGAATACAG-3' \\
\hline & probe & 5'- ROX-CACACCCGCCACCAGTTCGC-BHQ2-3' \\
\hline
\end{tabular}


To quantify the results obtained by real-time RT-PCR, we used the standard curve method. The value obtained for the level of expression of each gene was subsequently normalized to the mean of expression levels of Actb and Cphn.

The oligonucleotide primers and probes were synthesized based on the sequences chosen using BeaconDesigner 5.0 PCR primer designing software. PCR primer and probe sequences are shown in Table 1.

\section{Statistics}

Data were analyzed using one-way Kruskal-Wallis analysis of variance (ANOVA). A post-hoc comparison was made using Mann-Whitney test. The correlation between the Th, Dat1, Bdnf, and Snca mRNA levels was assessed using the Spearman correlation analysis for each experimental group separately: the controls, no-deprivation winners, post-deprivation winners and for combined data of all the experimental groups. Correlations were also calculated between the parameters of aggression (latency, number and total time of attacks) and the mRNA levels of the genes in the group of nodeprivation winners. In post-deprivation winners, correlations were calculated between postdeprivation mRNA levels and pre-deprivation behavioral parameters. Each experimental group contained 7-11 animals. The statistical significance was $\mathrm{P} \leq 0.05$.

\section{Results}

The winners that were included in the no-deprivation group and those to be subject to deprivation, did not differ in any parameter of individual or social behavior measured after the 20-day period of agonistic confrontations ( $\mathrm{P}>0.05$ for all parameters, Table 2$)$. Therefore, both groups are identical and can be used for finding out if deprivation has effects on the expression of the genes in question as

Table 2. Behavior of the mice to be included in the no-deprivation group and the mice to be included in the post-deprivation group. All data from the $20^{\text {st }}$ agonistic interaction.

\begin{tabular}{|c|c|c|c|}
\hline $\begin{array}{l}\text { Behavioral } \\
\text { parameters }\end{array}$ & $\begin{array}{c}\text { Mice to become } \\
\text { no-deprivation } \\
\text { winners }\end{array}$ & $\begin{array}{l}\text { Mice to become } \\
\text { post-deprivation } \\
\text { winners }\end{array}$ & $\begin{array}{c}\text { Mann-Whitney } \\
\text { test }\end{array}$ \\
\hline \multicolumn{4}{|l|}{ Attacks } \\
\hline Latency, s & $41.7 \pm 15.0$ & $68.9 \pm 39.5$ & $\mathrm{U}=27.0 ; \mathrm{NS}$ \\
\hline Number & $15.3 \pm 3.1$ & $12.0 \pm 2.8$ & $\mathrm{U}=34.5 ; \mathrm{NS}$ \\
\hline Total time, s & $81.4 \pm 20.8$ & $53.4 \pm 12.2$ & $\mathrm{U}=29.0 ; \mathrm{NS}$ \\
\hline \multicolumn{4}{|l|}{ Aggressive grooming } \\
\hline Latency, s & $584.5 \pm 15.5$ & $518.6 \pm 81.4$ & $\mathrm{U}=36.0 ; \mathrm{NS}$ \\
\hline Number & $0.2 \pm 0.2$ & $0.9 \pm 0.9$ & $\mathrm{U}=36.0 ; \mathrm{NS}$ \\
\hline Total time, s & $3.2 \pm 3.2$ & $9.4 \pm 9.4$ & $\mathrm{U}=36.0 ; \mathrm{NS}$ \\
\hline \multicolumn{4}{|l|}{ Diggings } \\
\hline Number & $10.2 \pm 1.7$ & $9.9 \pm 1.2$ & $\mathrm{U}=38.0 ; \mathrm{NS}$ \\
\hline Total time, $\mathrm{s}$ & $37.9 \pm 7.9$ & $43.6 \pm 3.0$ & $\mathrm{U}=28.0 ; \mathrm{NS}$ \\
\hline $\begin{array}{l}\text { Total time of hostile } \\
\text { behavior }\end{array}$ & $122.5 \pm 18.2$ & $106.4 \pm 10.9$ & $\mathrm{U}=33.0 ; \mathrm{NS}$ \\
\hline \multicolumn{4}{|l|}{ Self-grooming } \\
\hline Number & $4.5 \pm 1.1$ & $7.1 \pm 1.8$ & $\mathrm{U}=26.5 ; \mathrm{NS}$ \\
\hline Total time, s & $10.2 \pm 2.1$ & $13.3 \pm 3.5$ & $\mathrm{U}=33.0 ; \mathrm{NS}$ \\
\hline Number of animals & 11 & 7 & \\
\hline
\end{tabular}


well as if there are correlations between behavioral indices and gene expression before and after deprivation.

Kruskal-Wallis analysis revealed a significant influence of the groups factor on the mRNA level of Th gene $[\mathrm{H}(2,24)=7.11, \mathrm{P}<0.05]$ and Dat1 gene $[\mathrm{H}(2,25)=6.45, \mathrm{P}<$ $0.05]$, and a tendency-level influence on Snca gene $[\mathrm{H}(2,26)=5.80, \mathrm{P}=0.06]$. There was no significant influence of groups on the expression of the $B d n f$ gene $[\mathrm{H}(2,24)=0.16$, NS].

Further analysis by the Mann-Whitney test (Fig. 2) indicated that the no-deprivation winners had significantly increased mRNA levels of Th $(\mathrm{U}=10 ; \mathrm{P}<0.05)$, Dat1 $(\mathrm{U}=13 ; \mathrm{P}<$ $0.05)$, and Snca $(\mathrm{U}=16 ; \mathrm{P}<0.05)$ as compared to the controls. The post-deprivation winners had increased mRNA levels of Th and Dat1 as compared to the controls (for both comparisons, $\mathrm{U}=5 ; \mathrm{P}<0.05)$. The post-deprivation winners and controls did not differ in the mRNA level of Snca $(\mathrm{U}=21$; NS). The no- and post-deprivation winners did not differ in the mRNA level of Th $(\mathrm{U}=29$; NS) or Dat1 (U = 32; NS); for Snca, there was a tendency-level difference $(\mathrm{U}=22 ; \mathrm{P}=0.09)$.

Spearman analysis revealed a significant positive correlation between the mRNA levels of Th and Dat1 $(\mathrm{R}=0.943, \mathrm{P}<0.005)$, and Bdnf and Snca $(\mathrm{R}=0.893, \mathrm{P}<0.007)$ in the control animals (Table 3). Significant positive correlations between the Th and Dat1 mRNA
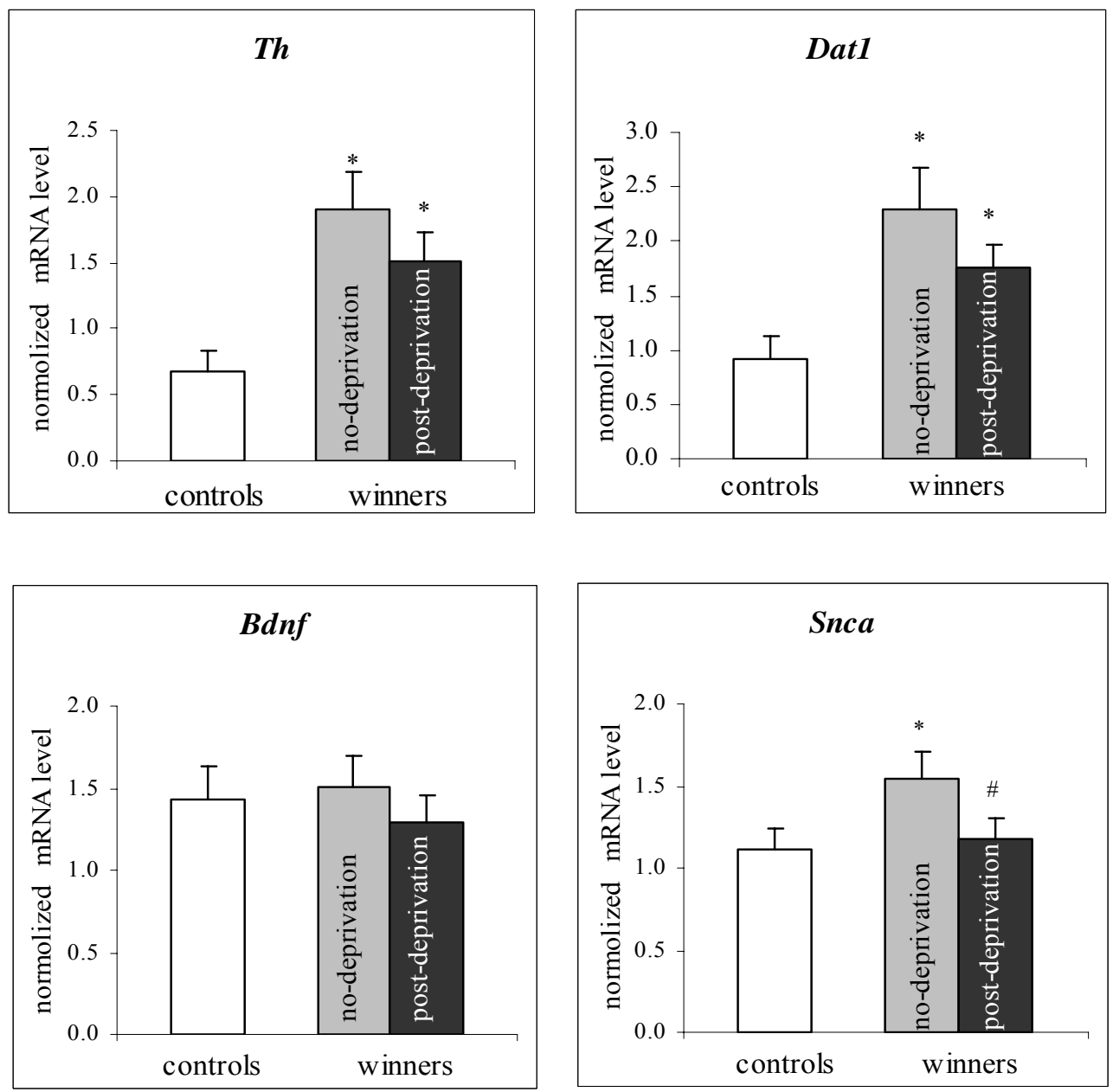

Figure 2. The normalized levels of mRNA of Th, Dat1, Snca and Bdnf genes in VTA of the control animals, no- and post-deprivation winners. $*$ - $\mathrm{P}<0.05$ vs the controls, \# - $\mathrm{P}$ $<0.1$ tendency-level difference vs no-deprivation winners (Mann-Whitney test) 
levels $(\mathrm{R}=0.891, \mathrm{P}<0.001)$ and the Dat1 and Snca mRNA levels $(\mathrm{R}=0.636, \mathrm{P}<0.026)$ were found in the no-deprivation winners. In the post-deprivation winners a significant positive correlation between the Th and Dat1 mRNA level $(\mathrm{R}=0.857, \mathrm{P}<0.014)$ was found. When the data on all experimental groups were pooled to find functional correlations between the mRNA levels of the genes, correlations were found between the mRNA levels of $T h$ and Dat1 $(\mathrm{R}=0.940, \mathrm{P}<0.001)$, Dat1 and Snca $(\mathrm{R}=0.456, \mathrm{P}<0.05)$, Snca and Bdnf $(\mathrm{R}=0.479$, $\mathrm{P}<0.05$ ) (Table 3).

Table 3. Significant correlations between the mRNA levels of the Th, Dat1, Snca and Bdnf genes in VTA of the controls, no-deprivation winners and post-deprivation winners

\begin{tabular}{|c|c|c|c|}
\hline Controls & $\begin{array}{c}\text { No-deprivation } \\
\text { winners }\end{array}$ & $\begin{array}{c}\text { Post-deprivation } \\
\text { winners }\end{array}$ & $\begin{array}{c}\text { Combined data of } \\
\text { all groups }\end{array}$ \\
\hline $\begin{array}{c}\text { Th ---- Dat1 } \\
* *\end{array}$ & $\begin{array}{c}\text { Th----Dat1----Snca } \\
* * *\end{array}$ & Th -----Dat1 & $\begin{array}{c}\text { Th-----Dat1----Snca----Bdnf } \\
* * *\end{array}$ \\
$\begin{array}{c}\text { Snca----Bdnf } \\
* *\end{array}$ & & $*$ \\
\hline
\end{tabular}

Note: Positive correlations: * $-\mathrm{P}<0.05$; ** $-\mathrm{P}<0.01$; *** $-\mathrm{P}<0.001$, Spearman test

Correlation analysis of the mRNA levels of the Th, Dat1, Snca and Bdnf genes in the nodeprivation animals and the parameters of their aggressive behavior revealed significant positive correlations between the Th mRNA level and the number of attacks $(\mathrm{R}=0.607, \mathrm{P}<0.05)$ and the total time of attacks $(\mathrm{R}=0.655, \mathrm{P}<0.05)$ and the Snca mRNA level and the number of attacks $(\mathrm{R}=0.699$, $\mathrm{P}<0.05)$ (Table 4). There was no significant correlation between the parameters of aggressive behavior and the Dat1 or Bdnf mRNA level. Correlation analysis of the parameters of aggressive behavior in the no-deprivation winners and the mRNA levels of the Th, Dat1, Snca and Bdnf genes in the post-deprivation winners revealed a positive correlation between the mRNA level of the Snca gene and the total time of attacks $(\mathrm{R}=0.821, \mathrm{P}<0.05)$ and a negative correlation with a latency to the first attack $(\mathrm{R}=-0.964, \mathrm{P}<0.001)$. There were no significant correlations between the attacking parameters and the mRNA levels of the Th, Dat1 or Bdnf genes.

Table 4. Significant correlations between the mRNA levels of the Th, Dat1, Snca and Bdnf genes in the VTA of pre- and post-deprivation winners and the level of aggression during the $20^{\text {st }}$ confrontation

\begin{tabular}{|ccc|}
\hline $\begin{array}{c}\text { Gene expressions in no- } \\
\text { deprivation winners }\end{array}$ & $\begin{array}{c}\text { Parameters of aggressive } \\
\text { behavior }\end{array}$ & $\begin{array}{c}\text { Gene expressions in } \\
\text { post-deprivation winners }\end{array}$ \\
\hline Latency, sec & & \multicolumn{1}{c}{ Th } \\
Dat1 & Attacks, sec & Dat1 \\
Snca & Attacks, N & Snca \\
Bdnf & Bdnf \\
\hline
\end{tabular}

Note: solid lines - positive correlation; dotted line - negative correlations, Spearman test

\section{Discussion}

This experiment demonstrates an increase of the Th and Dat1 mRNA levels in the VTA of the aggressive mice who were victorious for 20 days, which is similar to those in the winners for 10 
days ${ }^{12}$. Thus, a chronic manifestation of aggression, which is accompanied by a total activation of dopaminergic systems ${ }^{8,9}$, enhances the expression of the Th and Dat1 genes, whose products are responsible for the synthesis and inactivation of DA, respectively. In this respect, enhanced Snca gene expression may represent a feedback mechanism of DA re-uptake inhibition, providing an increased DA level in the synaptic cleft under the influence of repeated aggression. Positive fighting experience did not influence significantly Bdnf gene expression in the VTA. However, it has been reported that the expression of some genes may increase rapidly and decrease abruptly, while that of other genes changes more gradually ${ }^{26}$. Thus, the lack of changes in the Bdnf mRNA levels in the winners could be explained by transient (dynamic) changes of gene expression shown, for example, for genes of kappaopioid receptors ${ }^{27,28}$, mu-opioid receptors ${ }^{29-31}$, and proenkephalin ${ }^{32}$ in some brain areas in response to experimental settings. If so, we cannot completely exclude the involvement of Bdnf in the mechanisms of repeated aggression. This assumption is confirmed by the presence of a positive functional correlation between the Bdnf and Snca mRNA levels.

In the post-deprivation winners, the expression of the Th and Dat1 genes was still enhanced: the respective mRNA levels of these genes differed significantly from those in the control mice and did not differ significantly from those in the no-deprivation winners. On the one hand, it is possible that living in close habitation with a male behind the perforated transparent partition alerts the winners, and so they are aggressive even without fights. Another interpretation is that the enhanced expression of the genes as a result of repeated aggression is maintained by some molecular mechanisms, no matter which environment. Noteworthy, the post-deprivation level of aggression in the winners was increased as compared to that in pre-deprivation periods ${ }^{6}$. It is possible that the reason for this increase is the accumulation of DA due to an enhanced level of expression of the Th gene, which codes for the key enzyme in DA synthesis - TH. The level of Snca mRNA in the postdeprivation winners was decreased compared to that in no-deprivation winners and did not differ from that in the controls.

A significant positive correlations were found between Th and Dat1 mRNA levels in the VTA of the controls, no-deprivation and post-deprivation winners, which suggests a close relationship between dopamine synthesis and inactivation, possibly as a result of overlapping of Th and Dat1 mRNA-positive dopaminergic neurons ${ }^{15}$. The reason for this relationship might be common molecular mechanisms of transcriptional regulation of these genes. For example, it was shown that Nurr1 increases the transcriptional activity of both $T h$ and Dat1 promoters ${ }^{33}, 34$. A significant positive correlation between mRNA levels of the Snca and Bdnf genes was found in the control animals. It is possible that, in intact animals, the transcription factors that regulate the Th and Dat1 genes are not the same as those that regulate the Snca and Bdnf genes. An additional positive correlation between mRNA levels of the Dat1 and Snca genes was found in the no-deprivation winners, but not in the postdeprivation winners. In the post-deprivation winners, the mRNA level of the Snca gene has a tendency to recover to the no-deprivation level. That may imply that the Snca gene is involved in the mechanisms of dopaminergic activation due to repeated aggression. Pooled data on all the experimental groups (the controls, the no-deprivation winners and post-deprivation winners) revealed interrelations of mRNA levels in the following succession: Th---- Dat1---- Snca---- Bdnf. However, the intrinsic molecular mechanisms of this functional association that exists between the experience of behaving aggressively, Th, Dat1, Snca and Bdnf expression, and the implications of neurochemical events occurring in the brain of the winners have yet to be revealed. Interestingly, in the winners, there is an interplay between the level of aggression estimated by the latency to the first attack, the number and total time of attacks and Th and Snca mRNA levels in the VTA. It is therefore possible that the higher the level of aggression demonstrated by males in agonistic interactions, the higher the level of Th and Snca gene expression in their brain. These results are promising in that they can eventually help tell the state of a gene in the brain by simply watching individuals behave.

There are more experimental studies that provide support to the hypothesis that many genes can change their functional state due to social confrontations ${ }^{35}$. For example, repeated aggression resulted in a decrease of catechol-O-methyltransferase ${ }^{36,37}$ and kappa-opioid receptor ${ }^{28}$ mRNA levels in some brain areas of the winners. The induction of early genes in brain cells was found after single and repeated social defeat ${ }^{38,39}$ and acute conflict provoking aggression of mice towards one another ${ }^{40}$. Chronic social defeat stress increased mu-opioid receptors mRNA level in the VTA in rats $^{30}$ and monoamine oxidase A and serotonin transporter mRNA levels in the raphe nuclei of mice ${ }^{41}$. Chronic 
social defeat stress significantly increased CRE/CREB-directed gene expression ${ }^{42}$, TH protein ${ }^{43}$ and reduced $\mathrm{BDNF}^{44}$, glucocorticoid and mineralocorticoid receptor ${ }^{45}$ as well as interleukin (IL)-1beta mRNA levels ${ }^{46}$ in some brain regions. Berton and colleagues ${ }^{21}$ used DNA microarrays to examine gene transcription in the nucleus accumbens of male mice and reported 309 genes, which were upregulated just after 10 days of chronic social defeat, with 127 still elevated four weeks later, whereas 17 were immediately down-regulated, of which nine remained reduced four weeks later.

Prolonged experience of social confrontations and social stress has been shown to develop pathological states in animals (depression, anxiety, affective aggression) ${ }^{6,47,48}$. It is becoming clear that the development of psychoemotional disorders leads to changes in the transcriptional state of a set of genes, which makes it possible to track changes in gene functioning and to look for possibilities of their pharmacological correction. If this is as it seems to be, we should think of a new-generation therapy that can prevent gene expression from being affected by psychopathogenic factors.

\section{Acknowledgments}

This work was supported in part by a research grant (07-04-00014) from Russian Foundation for Basic Research and grant (10.13) from Molecular and Cellular Biology of Russian Academy of Sciences program N10.1. We are thankful to Vladimir Filonenko (fil@bionet.nsc.ru) for a thorough revision of the English version of this manuscript.

\section{References}

1. Association AP. Diagnostic and Statistical Manual of Mental Disorder (DSM-IV), fourth ed. APA: Washington DC, 1994.

2. Scott JP. Theoretical issues concerning the origin and causes of fighting. In: Eleftheriou BE, Scott JP (eds). The physiology of aggression and defeat. Plenum New-York, 1971, pp 11-42.

3. Moyer KE. Violence and Aggression. Paragon House: N.Y., 1987, 237pp.

4. Baron RA, Richardson D. Human aggression. Plenum Press: New York, 1994, 351pp.

5. Fish EW, De Bold JF, Miczek KA. Aggressive behavior as a reinforcer in mice: activation by allopregnanolone. Psychopharmacology (Berl) 2002; 163(3-4): 459-466.

6. Kudryavtseva NN. Psychopathology of repeated aggression: a neurobiological aspect. In: Morgan JP (ed). Perspectives on the Psychology of Aggression. NOVA Science Publishers, Inc, 2006, pp 35-64

7. Caramaschi D, de Boer SF, de Vries H, Koolhaas JM. Development of violence in mice through repeated victory along with changes in prefrontal cortex neurochemistry. Behav Brain Res 2008; 189(2): 263-272.

8. Kudriavtseva NN, Bakshtanovskaia IV. The neurochemical control of aggression and submission. Zh Vyssh Nerv Deiat Im I P Pavlova 1991; 41(3): 459-466.

9. Devoino LV, Idova GV, Al'perina EL, Cheido MA. The neurochemical set of the brain--an extra-immune mechanism of psychoneuroimmunomodulation. Vestn Ross Akad Med Nauk 1998; 9: 19-24.

10. Miczek KA, Faccidomo SP, Fish EW, DeBold JF. Neurochemistry and molecular neurobiology of aggressive behavior In: Lajtha A, Blaustein JD (eds). Handbook of Neurochemistry and Molecular Neurobiology: Behavioral neurochemistry, neuroendocrinology and molecular neurobiology. SpringerVerlag Berlin Heidelberg, 2007, pp 285-336.

11. Van Erp AM, Miczek KA. Aggressive behavior, increased accumbal dopamine, and decreased cortical serotonin in rats. J Neurosci 2000; 20(24): 9320-9325.

12. Filipenko ML, Alekseyenko OV, Beilina AG, Kamynina TP, Kudryavtseva NN. Increase of tyrosine hydroxylase and dopamine transporter mRNA levels in ventral tegmental area of male mice under influence of repeated aggression experience. Brain Res Mol Brain Res 2001; 96(1-2): 77-81.

13. Cooper SJ. Interaction between endogenous opioids and dopamine: Implications for reward and aversion. In: Willner P, Scheel-Kruger J (eds). The mesolimbic dopamine system: from motivation to action. John Wiley Sons Ltd: London, 1991, pp 331-366. 
14. Kudryavtseva NN. The sensory contact model for the study of aggressive and submissive behaviors in male mice. Aggress Behav 1991; 17(5): 285-291.

15. Hoffman BJ, Hansson SR, Mezey E, Palkovits M. Localization and dynamic regulation of biogenic amine transporters in the mammalian central nervous system. Front Neuroendocrinol 1998; 19(3): 187-231.

16. Miller GW, Gainetdinov RR, Levey AI, Caron MG. Dopamine transporters and neuronal injury. Trends Pharmacol Sci 1999; 20(10): 424-429.

17. Chen N, Reith ME. Structure and function of the dopamine transporter. Eur J Pharmacol 2000; 405(1-3): 329-339.

18. Abeliovich A, Schmitz Y, Farinas I, Choi-Lundberg D, Ho WH, Castillo PE et al. Mice lacking alphasynuclein display functional deficits in the nigrostriatal dopamine system. Neuron 2000; 25(1): 239-252.

19. Yavich L, Tanila H, Vepsalainen S, Jakala P. Role of alpha-synuclein in presynaptic dopamine recruitment. J Neurosci 2004; 24(49): 11165-11170.

20. Sidhu A, Wersinger C, Moussa CE, Vernier P. The role of alpha-synuclein in both neuroprotection and neurodegeneration. Ann N Y Acad Sci 2004; 1035: 250-270.

21. Berton O, McClung CA, Dileone RJ, Krishnan V, Renthal W, Russo SJ et al. Essential role of BDNF in the mesolimbic dopamine pathway in social defeat stress. Science 2006; 311(5762): 864-868.

22. Groves JO. Is it time to reassess the BDNF hypothesis of depression? Mol Psychiatry 2007; 12(12): 10791088.

23. Van Ree JM, Gerrits MA, Vanderschuren LJ. Opioids, reward and addiction: An encounter of biology, psychology, and medicine. Pharmacol Rev 1999; 51(2): 341-396.

24. Rosen GD, Williams AG, Capra JA, Connolly MT, Cruz B, Lu L et al. The Mouse Brain Library @ www.mbl.org. Int Mouse Genome Conference 14: 166. www.mbl.org. 2000.

25. Chomczynski P, Sacchi N. Single-step method of RNA isolation by acid guanidinium thiocyanate-phenolchloroform extraction. Anal Biochem 1987; 162(1): 156-159.

26. Nichols CD, Garcia EE, Sanders-Bush E. Dynamic changes in prefrontal cortex gene expression following lysergic acid diethylamide administration. Brain Res Mol Brain Res 2003; 111(1-2): 182-188.

27. Spangler R, Ho A, Zhou Y, Maggos CE, Yuferov V, Kreek MJ. Regulation of kappa opioid receptor mRNA in the rat brain by "binge' pattern cocaine administration and correlation with preprodynorphin mRNA. Brain Res Mol Brain Res 1996; 38(1): 71-76.

28. Goloshchapov AV, Filipenko ML, Bondar NP, Kudryavtseva NN, Van Ree JM. Decrease of kappa-opioid receptor mRNA level in ventral tegmental area of male mice after repeated experience of aggression. Brain Res Mol Brain Res 2005; 135(1-2): 290-292.

29. Azaryan AV, Clock BJ, Rosenberger JG, Cox BM. Transient upregulation of mu opioid receptor mRNA levels in nucleus accumbens during chronic cocaine administration. Can J Physiol Pharmacol 1998; 76(3): 278-283.

30. Nikulina EM, Hammer RP, Jr., Miczek KA, Kream RM. Social defeat stress increases expression of muopioid receptor mRNA in rat ventral tegmental area. Neuroreport 1999; 10(14): 3015-3019.

31. Yuferov V, Zhou Y, Spangler R, Maggos CE, Ho A, Kreek MJ. Acute "binge" cocaine increases mu-opioid receptor mRNA levels in areas of the rat mesolimbic mesocortical dopamine system. Brain Res Bull 1999; 48(1): 109-112.

32. Crespo JA, Manzanares J, Oliva JM, Corchero J, Palomo T, Ambrosio E. Extinction of cocaine selfadministration produces a differential time-related regulation of proenkephalin gene expression in rat brain. Neuropsychopharmacology 2001; 25(2): 185-194.

33. Zhang T, Jia N, Fei E, Wang P, Liao Z, Ding L et al. Nurr1 is phosphorylated by ERK2 in vitro and its phosphorylation upregulates tyrosine hydroxylase expression in SH-SY5Y cells. Neurosci Lett 2007; 423(2): 118-122.

34. Sacchetti P, Mitchell TR, Granneman JG, Bannon MJ. Nurr1 enhances transcription of the human dopamine transporter gene through a novel mechanism. J Neurochem 2001; 76(5): 1565-1572. 
35. Kudriavtseva NN, Filipenko ML, Bakshtanovskaia IV, Avgustinovich DF, Alekseenko OV, Beilina AG. Changes in the expression of monoaminergic genes under the influence of repeated experience of agonistic interactions: from behavior to gene. Russian Journal of Genetics 2004; 40(6): 590-604.

36. Filipenko ML, Beilina AG, Alekseyenko OV, Kudryavtseva NN. Changes of COMT gene expression under influence of agonistic confrontations in male mice. Dokl Akad Nauk 2001; 377: 1-4.

37. Filipenko ML, Beylina AG, Alekseyenko OV, Timofeeva OA, Avgustinovich DF, Kudryavtseva NN. Association between the brain COMT gene expression and aggressive experience in daily agonistic confrontations in male mice. In: McCarty R, Aguelera G, Sabban E, Kvetnansky R (eds). Stress: Neural, Endocrine and Molecular Studies. Taylor \& Francis: London \& New York, 2002, pp 157-161.

38. Kollack-Walker S, Don C, Watson SJ, Akil H. Differential expression of c-fos mRNA within neurocircuits of male hamsters exposed to acute or chronic defeat. J Neuroendocrinol 1999; 11(7): 547-559.

39. Martinez M, Phillips PJ, Herbert J. Adaptation in patterns of c-fos expression in the brain associated with exposure to either single or repeated social stress in male rats. Eur J Neurosci 1998; 10(1): 20-33.

40. Matsuda S, Peng H, Yoshimura H, Wen TC, Fukuda T, Sakanaka M. Persistent c-fos expression in the brains of mice with chronic social stress. Neurosci Res 1996; 26(2): 157-170.

41. Filipenko ML, Beilina AG, Alekseyenko OV, Dolgov VV, Kudryavtseva NN. Increase in expression of brain serotonin transporter and monoamine oxidase a genes induced by repeated experience of social defeats in male mice. Biochemistry (Mosc) 2002; 67(4): 451-455.

42. Boer U, Alejel T, Beimesche S, Cierny I, Krause D, Knepel W et al. CRE/CREB-driven up-regulation of gene expression by chronic social stress in CRE-luciferase transgenic mice: reversal by antidepressant treatment. PLOS ONE 2007; 2(5): e431.

43. Abumaria N, Rygula R, Hiemke C, Fuchs E, Havemann-Reinecke U, Ruther E et al. Effect of chronic citalopram on serotonin-related and stress-regulated genes in the dorsal raphe nucleus of the rat. Eur Neuropsychopharmacol 2007; 17(6-7): 417-429.

44. Pizarro JM, Lumley LA, Medina W, Robison CL, Chang WE, Alagappan A et al. Acute social defeat reduces neurotrophin expression in brain cortical and subcortical areas in mice. Brain Res 2004; 1025(1-2): $10-20$.

45. Meyer U, van Kampen M, Isovich E, Flugge G, Fuchs E. Chronic psychosocial stress regulates the expression of both GR and MR mRNA in the hippocampal formation of tree shrews. Hippocampus 2001; 11(3): 329-336.

46. Bartolomucci A, Palanza P, Parmigiani S, Pederzani T, Merlot E, Neveu PJ et al. Chronic psychosocial stress down-regulates central cytokines mRNA. Brain Res Bull 2003; 62(3): 173-178.

47. Kudryavtseva NN, Bakshtanovskaya IV, Koryakina LA. Social model of depression in mice of C57BL/6J strain. Pharmacol Biochem Behav 1991; 38(2): 315-320.

48. Kudryavtseva NN, Avgustinovich DF. Behavioral and physiological markers of experimental depression induced by social conflicts (DISC). Aggress Behav 1998; 24: 271-286. 